\title{
THERMODYNAMIC PREDICTION FOR DEVELOPMENT OF NOVEL ENVIRONMENTAL BIOTECHNOLOGIES AND VALUABLE PRODUCTS FROM WASTE OBTAINING
}

\author{
Oleksandr Tashyrev, Vira Hovorukha, Olga Suslova, Hanna Tashyreva, Olesya Havryliuk
}

\begin{abstract}
The aim of the work was to develop effective environmental biotechnologies enabling to stop pollution of environment with a wide range of toxicants and transform them into commercially valuable products. Using the method of thermodynamic prediction an algorithm to create new universal environmental biotechnologies was developed. Distinctive features of biotechnologies include: 1). fast and efficient disposal of a wide range of environmentally hazardous waste (decaying food and agricultural waste, synthetic organic compounds, and metal-containing waste water, etc.); 2). increase the efficiency of biotechnologies due to application of selected soil anaerobic microorganisms; 3). obtaining of a wide range of valuable products: gaseous fuels (hydrogen, methane), solid fuel (unfermented lignin and cellulose residues), concentrate of nonferrous metals (copper, chromium, etc.) and clean water; 4). ability to scale and replicate typical technologies of designated purpose. Obtained engineering and technological parameters of universal biotechnologies indicate the prospects of their large-scale industrial implementation.
\end{abstract}

Keywords: thermodynamic prediction, biotechnologies, environmentally hazardous compounds, synthetic organic compounds, metal-containing waste water, biohydrogen, biomethane

\section{INTRODUCTION}

Progressive pollution of environment with waste associated with human activities is one of the most dangerous sides of globalism at the world level. Until the middle of the twentieth century they believed that such environmentally hazardous compounds (xenobiotics) as synthetic organic compounds, toxic metals and radionuclides are the main danger for environment. However, decaying food waste of cities and mixed organic waste from household dumps are also considered to be extremely hazardous waste at the present time. Common property of these wastes is that their amount several orders exceeds the ability of both environmental technologies and ecosystems to decompose them.

Numerous attempts to create effective technologies to decompose these wastes were unsuccessful. It is evidenced by increase in volume and number of household dumps. In our opinion, it takes place due to the absence of theory that makes possible to predict "scenarios of evolution and migration" of waste in biosphere. Hence, successful solution of the problem is possible only on the basis of theoretical justification of the method for decomposition of these wastes and further - to choose optimal technology.

Therefore, we made an attempt to discover a theory of thermodynamic prediction (TDP) of microbial interaction with main classes of waste. This theory allows to calculate theoretically conditions necessary to "destabilize" any toxic compound and choose optimal type of microbial metabolism that allows to "destabilize", i.e. to decompose compounds related to specified wastes.
The aim of the work was to develop theoretical foundations of universal environmental biotechnologies that allow to stop pollution of environment with a wide range of toxic waste and transform them into commercially valuable products.

\section{MATERIALS AND METHODS}

Waste types. Diverse types of waste accumulated in the world are united by us into the following classes:

1. Toxic metals $\left(\mathrm{CrO}_{4}^{2-}, \mathrm{Cu}^{2+}, \mathrm{Hg}^{2+}, \mathrm{Co}^{2+}, \mathrm{Ni}^{2+}\right.$, etc.).

2. Synthetic organic compounds (nitrochloroaromatic and other aromatic compounds).

3. Solid natural organic compounds (food and agricultural waste).

Model toxic metals were $\mathrm{CrO}_{4}{ }^{2-}$ and $\mathrm{Cu}^{2+}$. Chromate was used in the form of $\mathrm{K}_{2} \mathrm{CrO}_{4}$. Copper was used in the form of citrate chelated $\mathrm{Cu}^{2+}$ cation. Concentration of metals by cation was $100-60000$ ppm of $\mathrm{CrO}_{4}{ }^{2-}$ and 200-30000 ppm of $\mathrm{Cu}^{2+}$.

1-chloro-3-nitrobenzene (CNB) at the concentration of 100-300 ppm was used as model synthetic organic compound.

Rotten vegetables and fruits raw and past cooked were solid organic waste (mixed food waste).

Thermodynamic prediction of microbial detoxification of xenobiotics. To develop the theoretical foundations of microbial technologies of xenobiotics decomposition, we used the method of thermodynamic prediction of microbial interaction with these types of compounds.

So, we calculated the stability fields of organic and inorganic compounds using Purbe diagrams in $\mathrm{pH}$-Eh coordinates [1]. The method enables to determine the stability fields of each compounds and to calculate the conditions necessary to destabilize 
toxic organic compounds or remove metals from solutions $[2,3]$.

The next step was to choose the type of microbial metabolism that led to kinetic destabilization of the toxicant (for example, destruction of organic compounds) or transformation of compounds into non-toxic form (for example, formation of insoluble metal compounds).

Microbial communities. Basing on experience to use microorganisms in biotechnologies it is suggested that pure cultures or microbial strains are ineffective because of their limited metabolic capacity. In addition, pure cultures are always contaminated by alien microorganisms in industrial bioreactors. Therefore, to decompose xenobiotics we used predominantly anaerobic soil microbial communities selected and adapted to toxicants.
Pure cultures (strains) of microorganisms were used to confirm thermodynamic prediction and discover theoretical regularities of interaction of microorganisms with xenobiotics. The following strains were used: Enterobacter hormaechei, Microbacterium trichothecenolyticum, Rhodococcus gingshengii, Candida tropicalis, Penicillium chrysogenum, Arthrobacter oryzae P11.

Lab-scale technology testing. Thermodynamically valid biotechnologies were tested in laboratory. For this purpose, direct flow modular installations were used to purify toxic filtrate from organic compounds, as well as model wastewater from toxic metals. Horizontal reactor with an integrated mechanism for waste stirring was used for controlled fermentation of solid food waste. Volume of the working chamber of reactor was 20 liters. (Fig. 1).

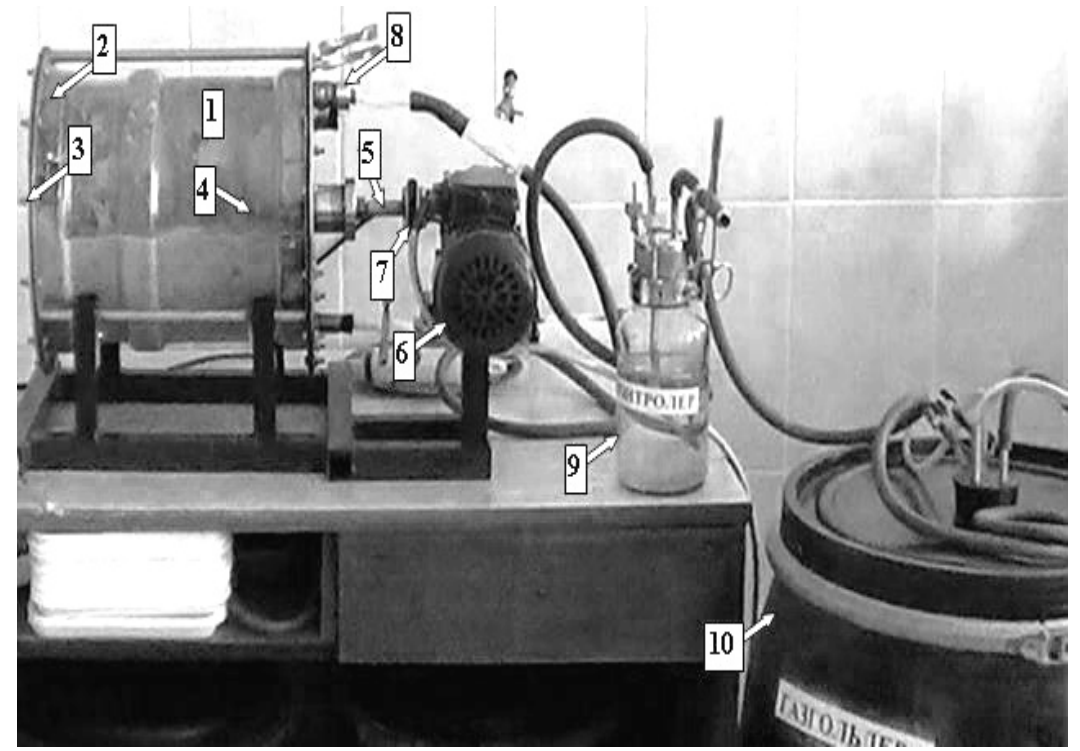

Fig. 1. General view of horizontal reactor: working chamber of reactor (1), flanges (2), rod-catches (3), rotor (4), drive shaft (5) connecting rotor to motor (6) through the gland (7), sockets (8), gas-controller (9), gas-holder (10)

The values of $\mathrm{pH}$ and redox potential were measured potentiometrically using $\mathrm{pH}$-metermillivoltmeter "pH-150 MA". Concentration of metals was determined by colorimetric methods based on the formation of colored complexes with metals [4]. 1chloro-3-nitrobenzene was extracted from culture liquid with hexane in a volume ratio of "culture liquid hexane" 1:5. Concentration of CNB and the product of its reduction, chloroaniline (CA), in hexane was measured by absorption in the ultraviolet spectrum $\left(\lambda_{\max } \mathrm{CNB}=260 \mathrm{~nm}, \lambda_{\max } \mathrm{CA}=245 \mathrm{~nm}\right)$ [5]. Concentration of organic compounds by total carbon was determined by the permanganate method [6]. Volume of synthesized gas was measured by volume of water displaced from the gasholder. Gas composition was determined by gas chromatographic method [7].

Engineering and technological parameters (ETP) of biotechnologies. The following ETP were used as the criteria of effectiveness of the process of waste destruction and synthesis of molecular hydrogen and methane:

- Time of destruction ( $T$, days) - duration of fermentation cycle till the moment of maximum destruction of waste and stabilization of culture medium parameters (end of gas synthesis, etc).

- Mass-balance of molecular hydrogen or methane, i.e. amount of liters of gas, synthesized from $1 \mathrm{~kg}$ of waste calculated for absolutely dry weight. 
- Coefficient of waste destruction $\mathrm{Kd}$ - the ratio of initial waste weight to final calculated for absolutely dry weight.

Commercially valuable products. During waste processing we solved the problem of waste destruction as well as valuable products obtaining. We have calculated mass-balance parameters of obtaining of such useful products as metal concentrate, gaseous energy carriers $\left(\mathrm{H}_{2}\right.$ and $\left.\mathrm{CH}_{4}\right)$, and water purified from metals.

\section{RESULTS AND DISCUSSION}

Using the TDP method an algorithm for creation of novel universal environmental biotechnologies has been developed.

Calculated stability limits of xenobiotics in $\mathrm{pH}$-Eh coordinates allowed to choose optimal types of microbial metabolism, that provided maximum environmental protection effect of xenobiotics detoxification. These effects were successfully shown during purification of metal-containing wastewater, as well as fermentation of solid food waste to produce energy carriers and other valuable products (concentrate of non-ferrous metals, clean water).

We will demonstrate the possibility to use thermodynamic prediction method on the example of theoretical calculation of optimal biotechnology for galvanic sewage purification from toxic compounds of $\mathrm{Cr}$ (VI).

Fig. 2 shows the stability fields of seven chromium compounds in $\mathrm{pH}$-Eh coordinates (values of Eh are indicated on the ordinate in the dimension of E, volts).

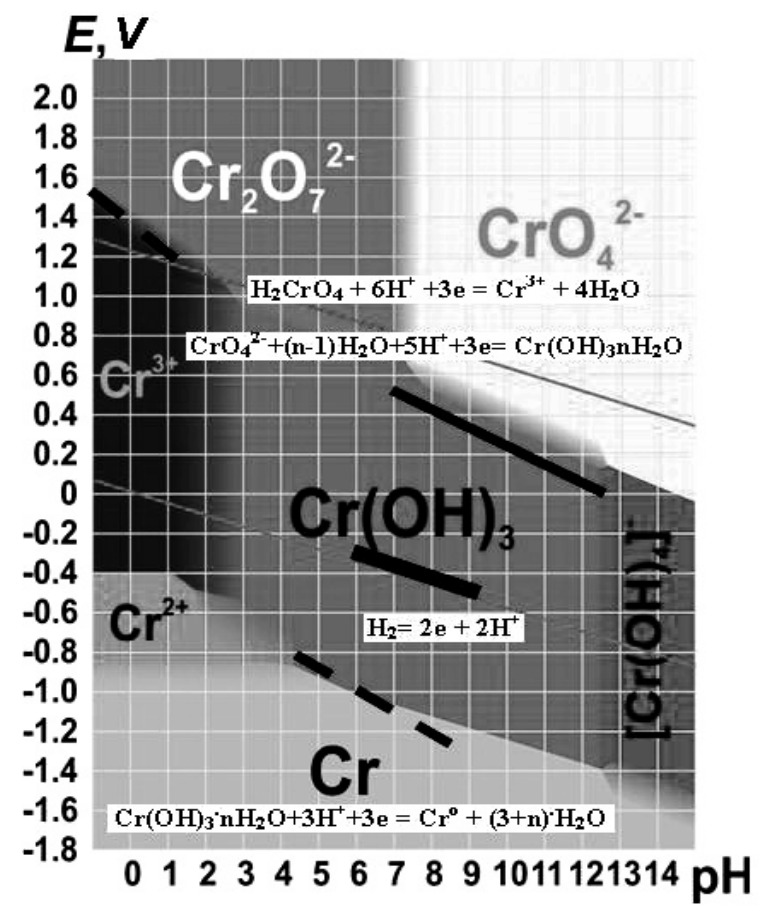

Fig. 2. Classical Pourbaix diagrams of Chromium compounds stability (in coordinates $\mathrm{pH}$ and Eh)

Previously, we showed that all the reactions of microbial metabolism, including reduction of metals can be carried out only in the zone of thermodynamic stability of water $[1,2]$. This zone is limited by upper and lower boundaries (Fig. 2). The upper limit (a) is described by the reaction equation $\mathrm{O}_{2}+4 \mathrm{H}^{+}=2 \mathrm{H}_{2} \mathrm{O}$ with the potential $\mathrm{E}_{\mathrm{o}}{ }^{\prime}=+814 \mathrm{mV}$ $(+0,814 \mathrm{~V})$, and the lower one (b) - by the equation $2 \mathrm{H}^{+}+2 \mathrm{e}=\mathrm{H}_{2}$ with the potential $\mathrm{E}_{\mathrm{o}}{ }^{\prime}=-414 \mathrm{mV}$ $(-0,414 \mathrm{~V})$.

Presented diagram shows that toxic compounds of $\mathrm{Cr}(\mathrm{VI})$ are in high redox potential zone, $\mathrm{Eh}=+400 \ldots+1400 \mathrm{mV}(\mathrm{pH}=0 . .14)$ in the form of $\mathrm{Cr}_{2} \mathrm{O}_{7}{ }^{2-}$ and $\mathrm{CrO}_{4}{ }^{2-}$. To purify galvanic drainage, it is necessary to transform soluble $\mathrm{Cr}(\mathrm{VI})$ compounds into insoluble compounds. Insoluble compounds are $\mathrm{Cr}(\mathrm{OH})_{3} \cdot \mathrm{nH}_{2} \mathrm{O}$ and $\mathrm{Cr}^{\circ}$.

It should be noted that redox potential of the lowestpotential metabolic reaction of microbial oxidation of $\mathrm{H}_{2}$ is $-414 \mathrm{mV}(\mathrm{pH}=7)$. Hence, it is obviously that microorganisms can not reduce $\mathrm{Cr}(\mathrm{VI})$ to metallic chromium, because potential of this acceptor reaction is several hundred millivolts lower than potential of donor reaction of hydrogen oxidation. Hence, it is obviously that microorganisms can provide removal of $\mathrm{Cr}(\mathrm{VI})$ compounds from solution only by $\mathrm{Cr}(\mathrm{VI})$ reduction to insoluble $\mathrm{Cr}(\mathrm{III})$ hydroxide. Indeed, the standard potential of $\mathrm{Cr}(\mathrm{VI})$ reduction is $+555 \mathrm{mV}$, and potential 
of $\mathrm{H}_{2}$ oxidation is $-414 \mathrm{mV}$. Hence, difference of potentials between electron donor $\left(\mathrm{H}_{2}\right)$ and acceptor $\left(\mathrm{CrO}_{4}^{2-}\right)$ is $969 \mathrm{mV}$. Obviously, such a significant difference of potentials between donor and acceptor reactions will provide inevitable rapid and effective reduction of $\mathrm{CrO}_{4}^{2-}$ to $\mathrm{Cr}(\mathrm{OH})_{3} \cdot \mathrm{nH}_{2} \mathrm{O}$ by microorganisms.

Thermodynamic prediction allows not only to determine necessary conditions for carrying out reaction of metal remove from solution, but also to choose the most effective way of its realization (Fig. 3). Aerobic, facultative and obligate anaerobic microorganisms are known to be able to reduce chromates to insoluble

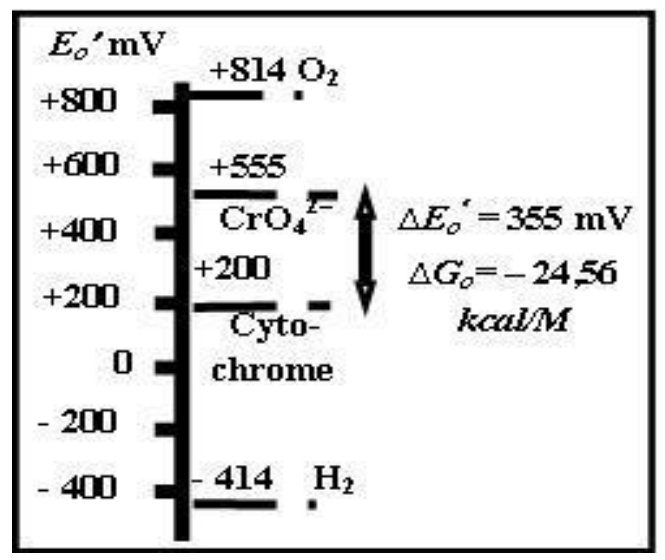

Cr(III) hydroxide [8]. Redox potential of overwhelming majority of intracellular carriers and redox systems of aerobic and facultative anaerobic microorganisms is known to be $+200 \mathrm{mV}$. Thus, potential of cytochrome $a$ is $+290 \mathrm{mV}$. Potentials of dehydrogenases (hydrogenases) of obligate anaerobic microorganisms are close to -414 $\mathrm{mV}$ [9]. Efficiency of $\mathrm{Cr}(\mathrm{VI})$ reduction by microorganisms is proportional to difference of potentials between donor system (microorganisms) and acceptor, i.e. $\mathrm{Cr}(\mathrm{VI})$. The larger this difference, the greater energy yield during chromate reduction. Consequently, its reduction is more efficient and fast.

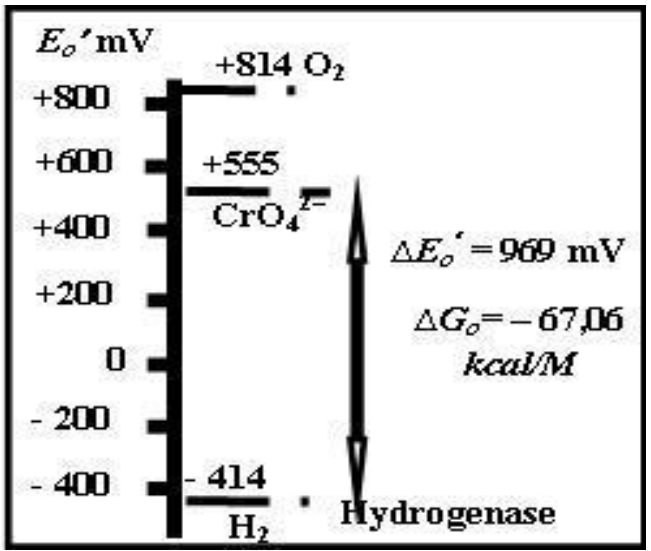

Fig. 3. Theoretical prognosis for discovering of optimal biotechnology

Free energy yield is described by equation [10]:

$\Delta G_{o}=-n \cdot F \cdot \Delta E_{o}=-n \cdot 23,067 \cdot \Delta\left(E_{o}\right.$ Acceptor -

$\left.E_{\text {o Donor }}\right), \mathrm{kcal} / \mathrm{M}$

When chromate is reduced by aerobic or facultative anaerobic microorganisms energy output is as follows:

$$
\begin{aligned}
& \Delta E_{o}=E_{C r(V I)}-E_{c y t}=+0,555-(+0,200)= \\
& =0,355 \mathrm{~V} \\
& \Delta G_{o}=-3 \cdot 23,067 \cdot \Delta E_{o}=-3 \cdot 23,067 \cdot 0,355= \\
& =-24,56 \mathrm{kcal} / \mathrm{M}
\end{aligned}
$$

When chromate is reduced by obligate anaerobic microorganisms energy output is:

$$
\begin{aligned}
& \Delta E_{o}=E_{C r(V I)}-E_{H 2}=+0,555-(-0,414)= \\
& =0,969 \mathrm{~V} \\
& \Delta G_{o}=-3 \cdot 23,067 \cdot \Delta E_{o}=-3 \cdot 23,067 \cdot 0,969= \\
& =-67,06 \mathrm{kcal} / \mathrm{M}
\end{aligned}
$$

Thus, the more negative is value of free energy yield, the more effective will be reduction of $\mathrm{Cr}(\mathrm{VI})$. Obviously, obligate anaerobic microorganisms will reduce chromate much more effective comparing to aerobic microorganisms. Yield of free energy $\left(\Delta \mathrm{G}_{\mathrm{o}}\right)$ during reduction of chromate by anaerobes is 2,7 times higher than by aerobes.

Unexpected, but extremely important conclusions follow obtained calculations. Realization of two seemingly incompatible processes is theoretically permissible and practically achievable: reduction of high-potential chromates by "low-potential" obligate anaerobes. Negative values of redox potential (not higher than $+200 \mathrm{mV}$ ) are required for the growth of anaerobes, and chromates provide potential about $+500 \ldots+600 \mathrm{mV}$. It is necessary to provide a spatial, stereometric differentiation of these processes to implement this process. Practically it means hydrogen fermentation of solid food waste (for example, potatoes) should be provided at the bottom of the cultivator (reactor) and reduction of chromates - in the upper part of the cultivator, i.e. in a layer of culture liquid.

Several important consequences arise from this:

1. Possibility of an "unusual" type of microbial metabolism by anaerobic microorganisms. This type of metabolism expect that glucose (starch monomer) is electron donor, $\operatorname{Cr}(\mathrm{VI})$ is electron acceptor, and microorganisms are "biocatalyst".

2. Simultaneous implementation in a single system (cultivator or industrial installation) of both environmental and commercially valuable positive processes. Environmental positive includes destruction of environmentally hazardous solid organic waste (reduction of their weight and volume), as well as purification of galvanic sewage from toxic chromate. 
Commercial positive effect is manifested in synthesis of environmentally friendly energy carrier (molecular hydrogen) and preparation of valuable metal concentrate in the form of insoluble $\mathrm{Cr}(\mathrm{OH})_{3} \cdot \mathrm{nH}_{2} \mathrm{O}$.

Our theoretical calculations concerning the possibility of microbial growth at ultrahigh concentrations of toxic metals is very important for development of novel effective environmental biotechnologies. We will show this on the example of $\mathrm{CrO}_{4}^{2-}$ (Fig. 4).

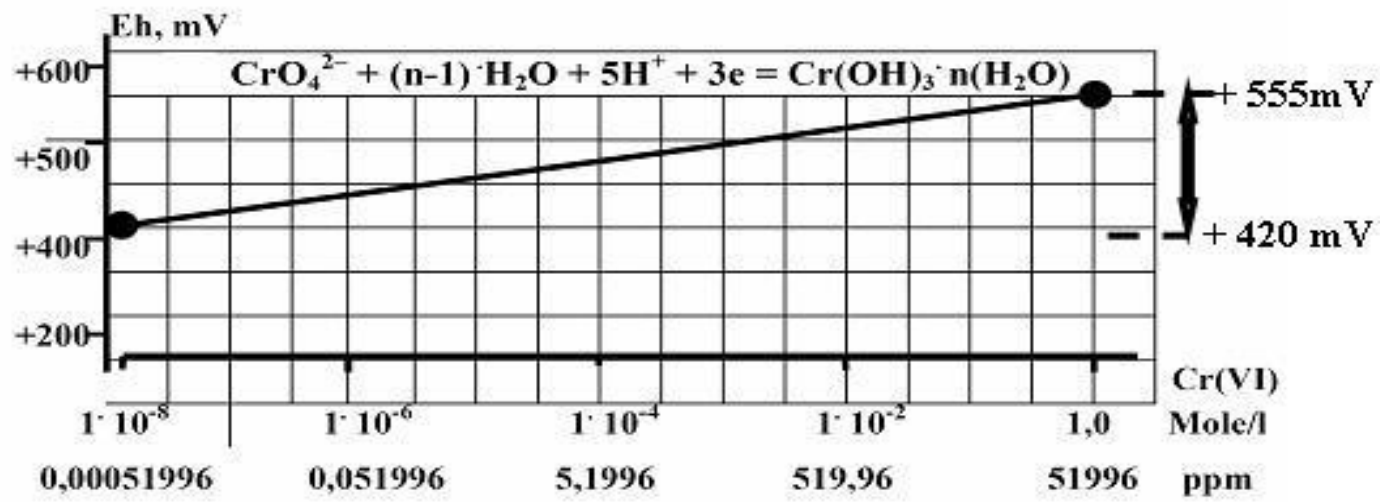

Fig. 4. Thermodynamic justification of possibility of microbial growth at super high concentrations of $\mathrm{Cr}(\mathrm{VI})$

One of the central points of the theory of thermodynamic prediction is the following. Redox potential of reaction of microbial reduction of metals within the zone of thermodynamic stability of water is necessary and sufficient condition for this reaction. Fig. 4 shows that 8 orders increase in concentration of $\mathrm{Cr}(\mathrm{VI})$, from $1 \cdot 10-8(0,0005 \mathrm{ppm})$ to $1,0 \mathrm{M}(51,996 \mathrm{ppm})$, leads to redox potential increase 1,3 times (from +420 to +555 $\mathrm{mV})$. In addition, the redox potential of $\mathrm{Cr}(\mathrm{VI})$ at $1,0 \mathrm{M}$ concentration is inside of the zone of thermodynamic stability of water. It is $259 \mathrm{mV}$ less than potential of the upper boundary of water stability $\left(\mathrm{E}_{\mathrm{o}}{ }^{\prime}=+814 \mathrm{mV}\right)$. Thus, we suggest that microorganisms can grow even in the presence of a single-molar concentration of $\mathrm{Cr}(\mathrm{VI})$ and reduce it to insoluble $\mathrm{Cr}(\mathrm{OH})_{3} \cdot \mathrm{nH}_{2} \mathrm{O}$.
Redox potential of culture liquid is always reduced to $-300 \ldots-400 \mathrm{mV}$ during hydrogen fermentation of organic compounds. Thus, low-potential process of hydrolysis of polymers by microorganisms (for example, potato starch) can be applied to reduce a wide range of toxic high-potential metals-oxidizers $\left(\mathrm{CrO}_{4}^{2-}\right.$, $\mathrm{VO}_{3}^{-}, \mathrm{MoO}_{4}^{2-}, \mathrm{Cu}^{2+}, \mathrm{Hg}^{2+}$, etc.). Indeed, anaerobic bacteria hydrolyze potato starch to glucose (Fig. 5.1). Then it is fermented to final products - hydrogen and $\mathrm{CO}_{2}$, decreasing potential to $\mathrm{Eh}=-300 \ldots-400 \mathrm{mV}$ (Fig. 5.2). Standard redox potential of chromate reduction to $\mathrm{Cr}$ (III) hydroxide is $\mathrm{E}_{\mathrm{o}}{ }^{\prime}=+555 \mathrm{mV}$. Hence, "lowpotential" anaerobic bacteria are donor system respecting to high-potential chromates that are acceptor system (Fig. 5.3).

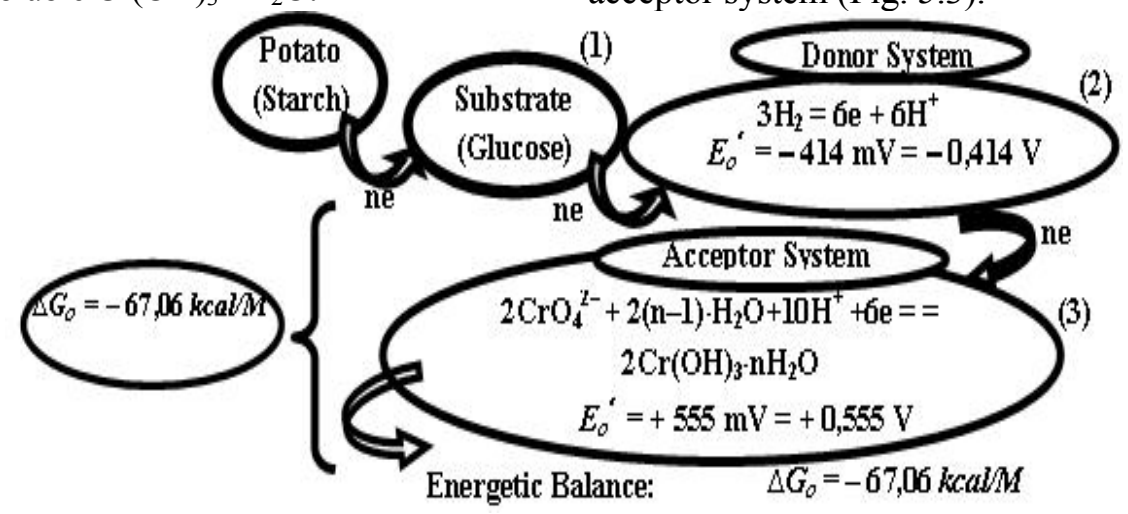

Fig. 5. Energetic content of coupled redox-reactions hydrogen fermentation of glucose and reduction of chromate

Difference of potentials between donor and acceptor systems equal $969 \mathrm{mV}$ provides high free energy yield for this coupled redox reaction: $\Delta \mathrm{G}_{\mathrm{o}}=-67,06 \mathrm{kcal} / \mathrm{M}$. Energy yield for this reaction is $10,41 \mathrm{kcal} / \mathrm{M}$ higher than even for biochemical oxidation of $\mathrm{H}_{2}$ under aerobic conditions. Thus, energy yield for the reaction $2 \mathrm{H}_{2}+\mathrm{O}_{2}=$ $2 \mathrm{H}_{2} \mathrm{O}$ in accordance with the equation $\Delta E_{o}=E_{O 2}-E_{H 2}$ $=+0,814-(-0,414)=1,228 \mathrm{~V}(1228 \mathrm{mV})$ is $\Delta G o=-$ $2 \cdot 23,067 \cdot \Delta E o=-3 \cdot 23,067 \cdot 1,228=-56,65 \mathrm{kcal} / \mathrm{M}$. It follows that coupled reaction of hydrogen fermentation 
of starch and reduction of chromates is not only permissible but thermodynamically unavoidable.

Experimental confirmation of thermodynamic prediction of microbial interaction with metals

Theoretical calculations were confirmed experimentally (Fig. 6). During hydrogen fermentation of raw potato starch microorganisms decreased redox potential of medium to $-360 \ldots-380 \mathrm{mV}$ and synthesized
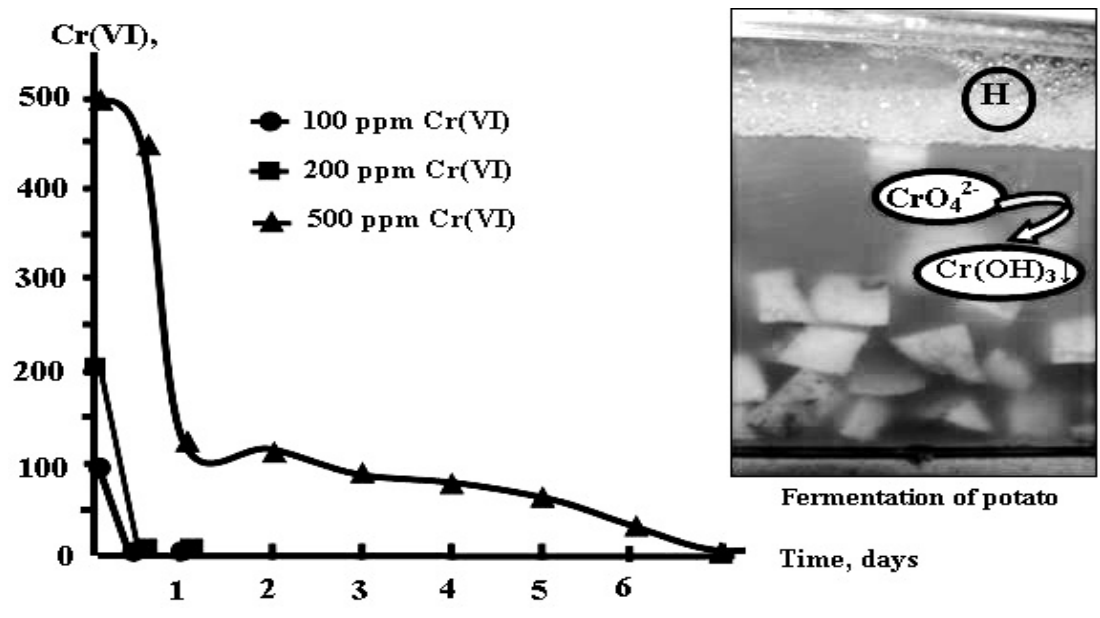

Fig. 6. Reduction of chromate coupled with $\mathrm{H}_{2}$ fermentation of potato

However, $\mathrm{Cr}(\mathrm{VI})$ was inevitably and rapidly reduced to insoluble $\mathrm{Cr}$ (III) hydroxide due to difference of potentials between electron donor $\left(\mathrm{H}_{2}\right)$ and acceptor $\left(\mathrm{CrO}_{4}{ }^{2-}\right)$ equal $969 \mathrm{mV}$. Complete reduction of chromates took place during 12 hours after its addition to growing culture at the concentration of 100 and 200 $\mathrm{ppm}$. However, further increase in concentration of $\mathrm{Cr}(\mathrm{VI})$ led to inhibition of its reduction. Thus, increase in concentration to $500 \mathrm{ppm}$ led to 14 times increase in the duration of chromate reduction to 168 hours (7 days). Growth of microorganisms and hydrogen synthesis resumed after complete reduction of toxic

$$
\mathrm{E}^{\prime}, \mathrm{mV}
$$

hydrogen in concentration of $35 \%$. Optical density was increased to 1,9 units of optical density. Such low potential predetermines rapid and efficient reduction of high-potential electron acceptor $\mathrm{Cr}(\mathrm{VI})$. When highpotential metal-oxidizer $\mathrm{Cr}(\mathrm{VI})$ was injected naturally redox potential of medium increased to $+400 \mathrm{mV}$. This led to inhibition of microbial growth and hydrogen synthesis.

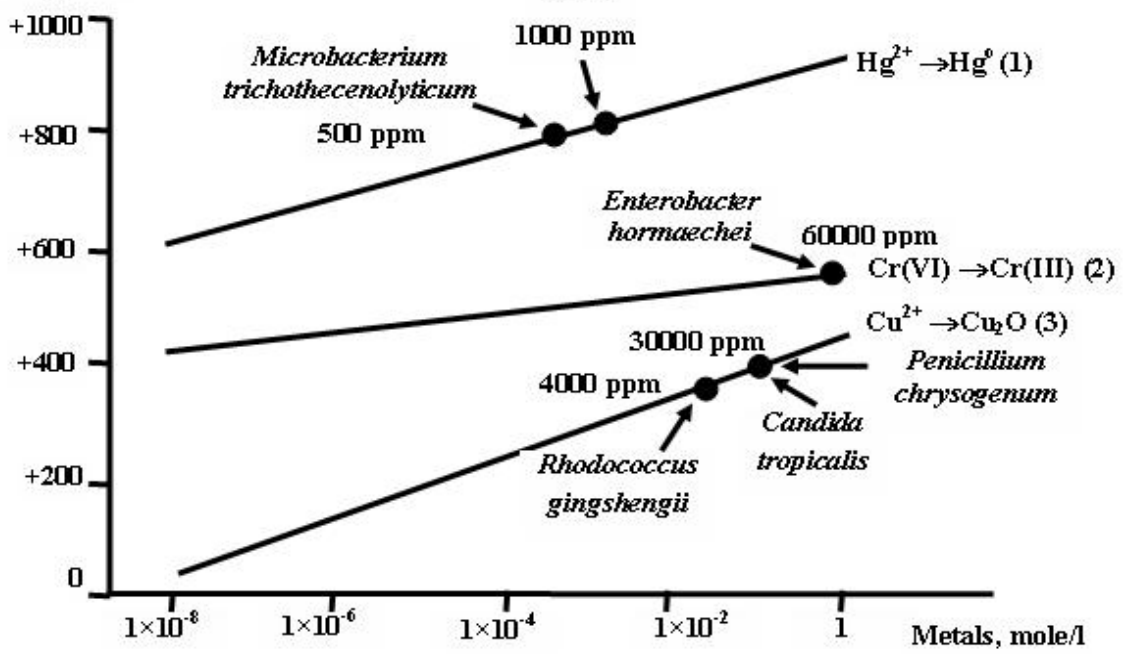

Fig. 7. Resistance of microorganisms to extremely high concentrations of toxic metals 
Thermodynamically valid possibility of microbial growth at ultrahigh concentrations of toxic metals has also been experimentally confirmed for $\mathrm{Hg}$ (II) and $\mathrm{Cu}$ (II) compounds. Redox potential of reaction $\mathrm{Hg}_{2}{ }^{2+}+2 \mathrm{e}=\mathrm{Hg}^{\mathrm{o}}$ is $+789 \mathrm{mV}$ at one-molar concentration of $\mathrm{Hg}_{2}^{2+}$. Therefore, it was quite natural to isolate microorganisms growing at ultrahigh concentrations of $\mathrm{Hg}(\mathrm{II})$. Thus, selected by us microorganisms grew at concentration of $1000 \mathrm{ppm}$ of $\mathrm{Hg}_{2}{ }^{2+}$ and reduced soluble $\mathrm{Hg}(\mathrm{II})$ to $1 \mathrm{ppm}$ during three days. The possibility of growth of Microbacterium trichothecenolyticum isolated from Antarctic soil (Argentinean archipelago, Galindez Island) in the presence of $500 \mathrm{ppm}$ of $\mathrm{Hg}_{2}{ }^{2+}$ suggests that potential resistance of some microorganisms to high concentrations of metal is general biological regularity. It is confirmed by growth of Rhodococcus gingshengii (Antarctic soil, King-George Island) at $4000 \mathrm{ppm}$ of $\mathrm{Cu}(\mathrm{II})$, as well as Candida tropicalis and Penicillium chrysogenum (Ecuador, clif $4000 \mathrm{~m}$ ) at $30000 \mathrm{ppm}$ of
$\mathrm{Cu}$ (II) [11]. Such high resistance to $\mathrm{Cu}(\mathrm{II})$ is explained by the fact that even at one-molar concentration of $\mathrm{Cu}$ (II) potential of its reduction reactions is within the limits of thermodynamic stability of water. Thus, $\mathrm{Eh}=$ $+153 \mathrm{mV}$ for the reaction $\mathrm{Cu}^{2+}+\mathrm{e}=\mathrm{Cu}(\mathrm{I})$, and $\mathrm{Eh}=$ $+255 \mathrm{mV}$ for the reaction $2 \mathrm{CuO}+2 \mathrm{H}^{+}+2 \mathrm{e}=\mathrm{Cu}_{2} \mathrm{O}+$ $\mathrm{H}_{2} \mathrm{O}$. Most of microorganisms resistant to metals interact with them: reduce to insoluble compounds or accumulate in cells [13].

Obtained theoretical regularities of microbial interaction with metals as well as their experimental confirmation were further developed into new environmental pilot biotechnologies. Thus, we have shown that selected microorganisms purified metalcontaining wastewater with high efficiency. For example, concentration of $\mathrm{Cu}^{2+}$ decreased in 3250 times from 325 to $0,1 \mathrm{ppm}$ in the direct flow modular pilot installation (Fig. 8)[14]. Similar results were obtained during purification of galvanic sewage from $\mathrm{CrO}_{4}^{2-}[8]$.

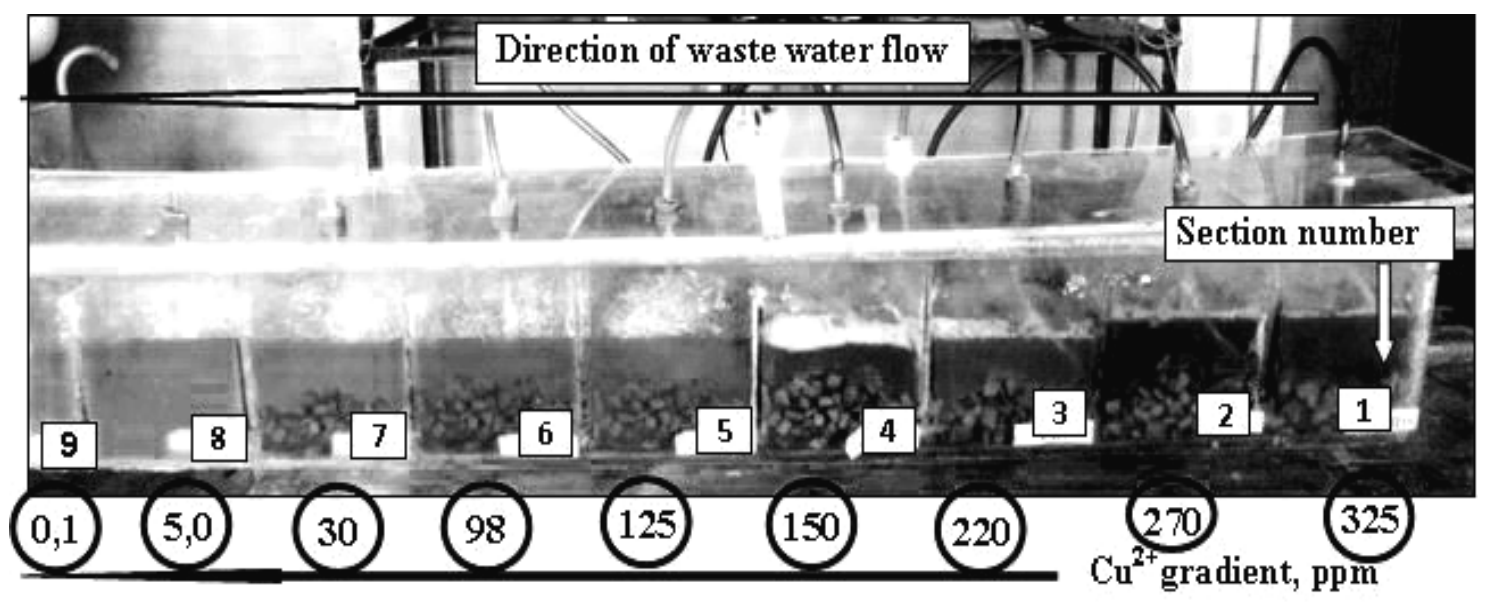

Fig. 8. Model drain purification from $\mathrm{Cu}^{2+}$ in direct flow installation (10 sections) by Antarctic Brevibacterium antarcticum 3204

It should be emphasized that functioning of the installation provides not only highly efficient deep purification of water from metals, but also obtaining of commercially valuable products: concentrate of metals in the form of insoluble compounds $\mathrm{Cu}_{2} \mathrm{O}$ and $\mathrm{Cr}(\mathrm{OH})_{3} \cdot \mathrm{nH}_{2} \mathrm{O}$. In addition, it is possible to obtain valuable product from $\mathrm{Cr}(\mathrm{OH})_{3} \cdot \mathrm{nH}_{2} \mathrm{O}$ - a technical abrasive in the form of crystalline $\mathrm{Cr}_{2} \mathrm{O}_{3}$. This abrasive is obtained by annealing $\left(800^{\circ} \mathrm{C}\right)$ of $\mathrm{Cr}(\mathrm{III})$ hydroxide. After $\mathrm{Cr}(\mathrm{III})$ hydroxide is annealed its weight is decreased in 2,8 times.

Experimental confirmation of thermodynamic prediction of microbial interaction with synthetic organic compounds

On the example of 1-chloro-3-nitrobenzene and the dye "direct blue light KU" (DBLKU) the prospects for thermodynamic evaluation of metabolic pathways for the destruction of toxic synthetic organic compounds for the creation of new environmental biotechnologies was shown. These compounds are persistent for microorganisms due to peculiarities of their structure. Thus, CNB structure includes an aromatic ring resistant to microbial attack, as well as nitro group and chlorine atom connected with aromatic ring:

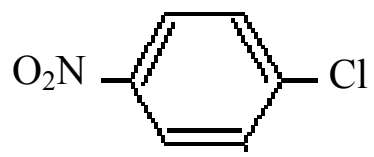

DBLKU is even more persistent compound since it contains three binary aromatic rings connected by diazo bonds: 


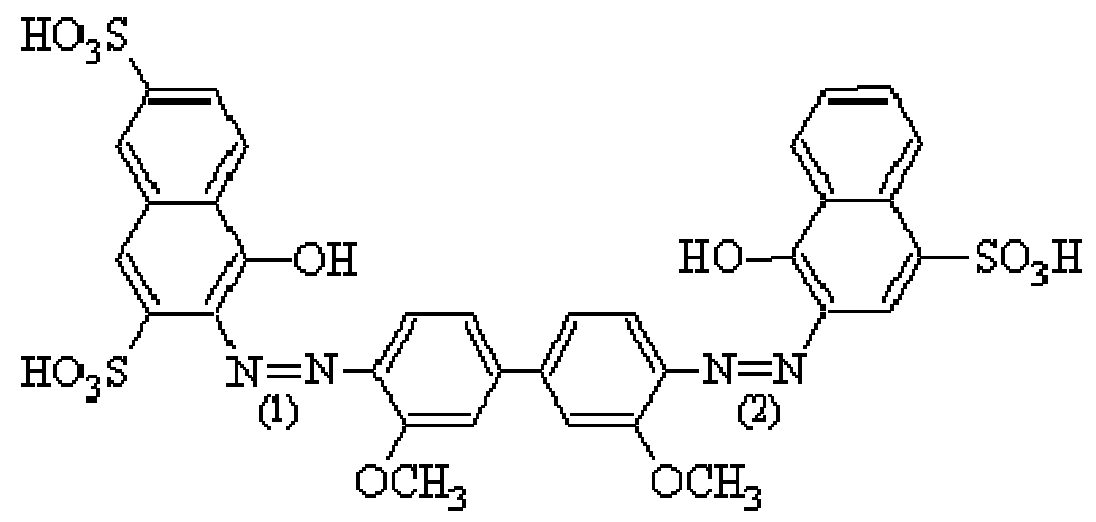

The total reductive level of carbon is -2 in $\mathrm{CNB}$, (for comparison, carbon reductive level in $\mathrm{CO}_{2}$, is +4 , and in methane equal -4$)$. It follows that both oxidative and reductive transformation of $\mathrm{CNB}$ are thermodynamically permissible (Fig. 9).

Two possible pathways:

\section{Aerobic oxidative pathway}

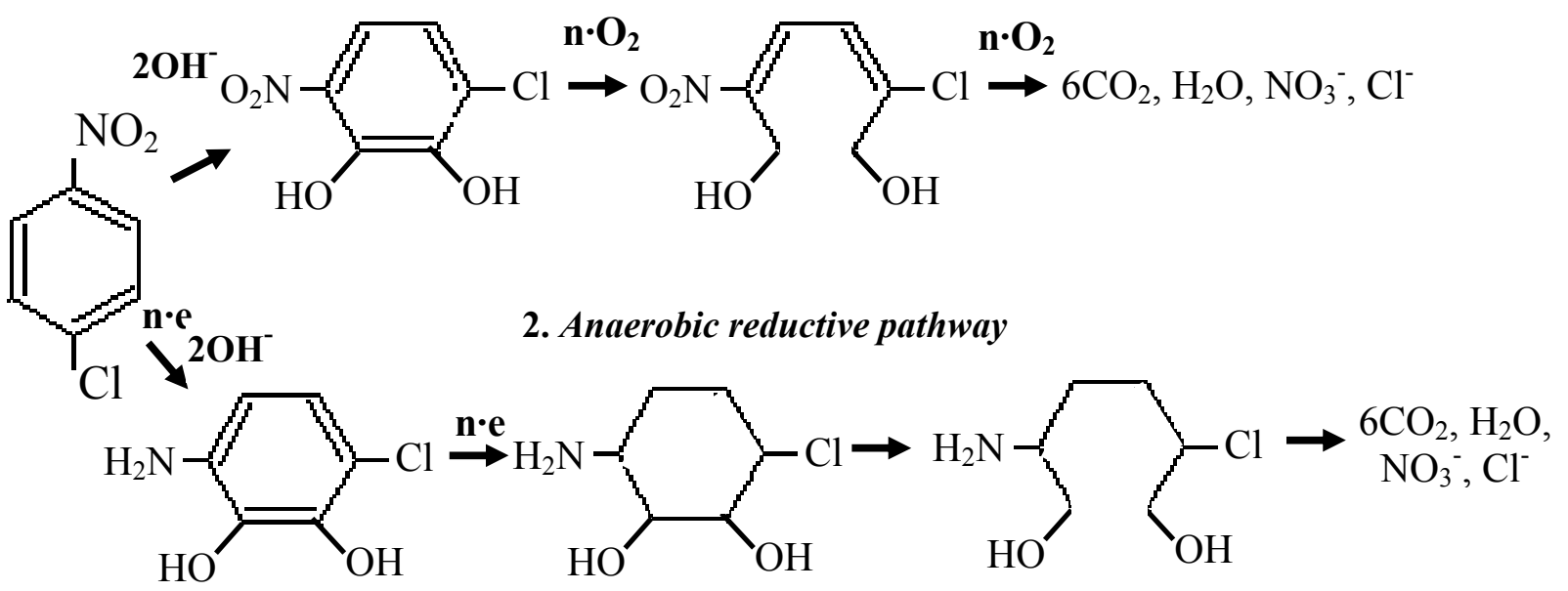

Fig. 9. Theoretical background of metabolic pathways for destruction of toxic synthetic organic compounds

However, oxidative pathway of destruction is extremely difficult for microorganisms, since it requires functioning of specific oxidases resistant to toxic effects of nitrochloroaromatic compounds. On the contrary, reductive pathway for CNB destruction can be carried out by microorganisms that are not specifically adapted to this compound. So, in the presence of easily digestible source of carbon and energy (electron donor), for example, glucose from starch, microorganisms oxidize it and simultaneously reduce available electron acceptors (for example, $\mathrm{O}_{2}$, $\left.\mathrm{NO}_{3}{ }^{-}, \mathrm{SO}_{4}{ }^{2-}, \mathrm{H}^{+}\right)$. Part of electron flow not only reduce terminal acceptors in the presence of $\mathrm{CNB}$, but also reduce nitro group and unsaturated bonds of the aromatic ring takes place. As a consequence, microorganisms further easily destroy unstable cyclic derivative to final products $\left(\mathrm{CO}_{2}, \mathrm{H}_{2} \mathrm{O}, \mathrm{NH}_{4}{ }^{+}, \mathrm{Cl}^{-}\right)$.
Apparently, reductive destruction of DBLKU occurs in a similar way.

So, availability of easily destroyable source of carbon and energy (electron donor) in the absence of terminal electron acceptors competitive to aromatic compounds (for example, $\mathrm{O}_{2}, \mathrm{NO}_{3}{ }^{-}$) is necessary and sufficient condition for nonspecific reductive destruction of aromatic compounds by microorganisms.

As evidence, we can mention reductive destruction of CNB followed by decomposition of reduced aromatic ring by the strain Arthrobacter oryzae P11 isolated from the clay of the karst cave Mushkarova Yama [5]. During 3 days microorganisms reduced $\mathrm{CNB}$ to an intermediate, chloroaniline, and then to derivatives that did not contain an aromatic ring. Underground karst caves isolation from external extreme factors including various pollutants especially aromatic compounds is their 
outstanding feature. Consequently, a priori there are no microorganisms adapted to nitrochloroaromatic compounds in a cave. In addition, 5 strains of bacteria were isolated from the vertical abyss Kuibyshevskaya (ecologically clean high-mountainous Caucasus). They were isolated from clays at the depth of $1 \mathrm{~km}$. These strains were resistant to ultrahigh concentration -300 ppm of CNB. Thus, it is obviously that thermodynamically based pathway of reductive destruction of aromatic compounds can be carried out by microbial communities not adapted to them.

We did not conduct detailed studies of derivatives of aniline dyes. However, analogically to
CNB we assumed that destructive degradation of persistent dye DBLKU will occur in the anaerobic conditions in the presence of an additional source of carbon and energy. Indeed, selected anaerobic microorganisms completely destroyed DBLKU at concentration of $10000 \mathrm{ppm}$ during 7 days (Fig. 10). As the result dye solution was completely and irreversibly discolored. Irreversible discoloring of DBLKU is the evidence of destruction of aromatic ring. It is necessary to emphasize that dyes are not destroyed for decades in the basins of sewage industrial collectors though their concentration significantly less $-1000 \mathrm{ppm}$.

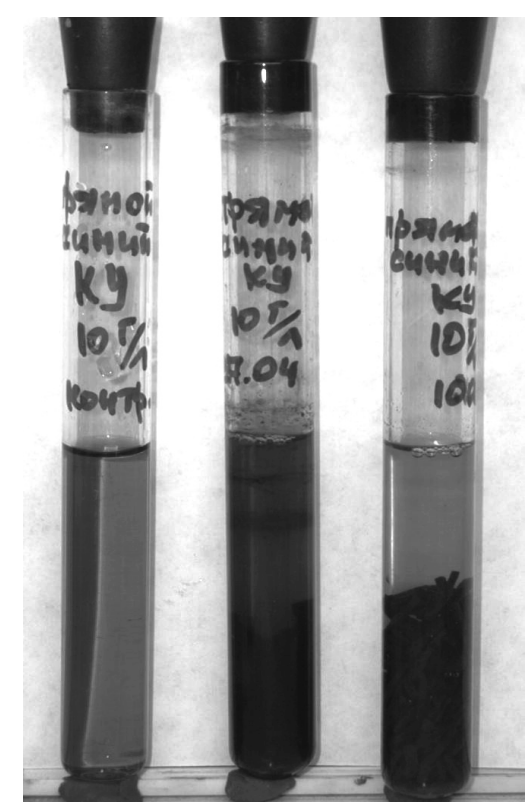

Fig. 10. Destruction of persistent dye DBLKU by selected anaerobic microorganisms

Obtained data testify that thermodynamically grounded reductive destruction of aromatic compounds by microorganisms is a promising decision for development of novel effective environmental biotechnologies.

Experimental confirmation of thermodynamic prediction of microbial interaction with solid natural organic compounds

The thermodynamic prediction method allows to theoretically substantiate and significantly improve biotechnology of fermentation of ecologically dangerous mixed food wastes. The method makes possible to evaluate the prospects to apply metabolic pathways for organic compounds destruction promising for development of effective biotechnologies. It is important for creation of theoretical basis for environmental biotechnologies, for example, destruction of environmentally hazardous and toxic mixed food waste. Plant polymers, starch, etc. are dominant in these waste. Therefore prediction method should be applied to select effective pathway for degradation of starch.

We will consider the effectiveness of three metabolic pathways of starch destruction from the standpoint of thermodynamics: aerobic oxidation, sulfate respiration, and butyric (hydrogen) fermentation. First stage of starch degradation is common for the three pathways. That is starch hydrolysis to glucose:

$$
\left[\mathrm{C}_{6} \mathrm{H}_{12} \mathrm{O}_{6}\right]_{\mathrm{n}} \rightarrow n \mathrm{C}_{6} \mathrm{H}_{12} \mathrm{O}_{6}
$$

Six moles of $\mathrm{O}_{2}$ are necessary for complete aerobic oxidation of glucose:

$$
\mathrm{C}_{6} \mathrm{H}_{12} \mathrm{O}_{6}+6 \mathrm{O}_{2} \rightarrow 6 \mathrm{H}_{2} \mathrm{O}+6 \mathrm{CO}_{2}+2800 \mathrm{~kJ}
$$

The molar ratio of glucose and oxygen, equal to $1: 6$, indicates the necessity of a very active aeration of culture medium. The limitation of glucose oxidation by oxygen is further enhanced by the fact that oxygen concentration in air is only $21 \%$, instead of $100 \%$ (see reaction equation). In addition, the rate of $\mathrm{O}_{2}$ diffusion into culture medium is incommensurably small 
compared with the rate of its consumption. So, spontaneous anaerobic fermentation of food waste will dominate due to these reasons during aerobic degradation of starch. It may lead to synthesis of the whole spectrum of toxic compounds: low molecular weight fatty acids, ammonia, mercaptans, etc. Hence, it is obvious that aerobic metabolic pathway is not applicable for destruction of starch, and its monomer glucose for biotechnology.

Let's consider destruction of starch under metabolic pathway of sulfate respiration (dissimilatory sulfate reduction). To oxidize 1 mole of glucose 3 moles of $\mathrm{SO}_{4}{ }^{2-}$ are necessary.

$$
\mathrm{C}_{6} \mathrm{H}_{12} \mathrm{O}_{6}+3 \mathrm{SO}_{4}^{2-} \rightarrow 3 \mathrm{~S}^{2-}+6 \mathrm{CO}_{2}+6 \mathrm{H}_{2} \mathrm{O}
$$

Thus, molar ratio of acceptor (sulphate) should be three times larger than electron donor (glucose) for effective destruction of starch. Obviously, this metabolic pathway is in principle unacceptable for industrial largetonnage biotechnology since the necessity to inject sulfates in large quantities. In addition, toxic hydrogen sulphide occurs as a product of sulfate reduction. So, additional very complicated and costly biotechnological operations are required to remove it (for example, the binding of sulphide with $\mathrm{Fe}^{2+}$ to form insoluble $\mathrm{FeS}$ ).

"Hydrogen" fermentation of glucose occurs without participation of terminal electron acceptors. Fermentation occurs along the path of disproportionation, i.e. one part of glucose molecule is oxidized to $\mathrm{CO}_{2}$, and another is reduced to $\mathrm{H}_{2}$ :

$$
\mathrm{C}_{6} \mathrm{H}_{12} \mathrm{O}_{6} \rightarrow 6 \mathrm{H}_{2}+6 \mathrm{CO}_{2}
$$

Such metabolic pathway provides not only effective degradation of starch, but also leads to synthesis of ecologically clean energy carrier $-\mathrm{H}_{2}$.

During butyric hydrogen fermentation from one mole of glucose 2 moles of energy carrier $\left(\mathrm{H}_{2}\right)$ is synthesized:

$$
\mathrm{C}_{6} \mathrm{H}_{12} \mathrm{O}_{6} \rightarrow \mathrm{C}_{2} \mathrm{H}_{5} \mathrm{COOH}+2 \mathrm{CO}_{2}+2 \mathrm{H}_{2}
$$

Thus, it is promising to use this metabolic pathway for theoretical justification and practical implementation of biotechnology.

The theory of biotechnological process allows to anticipate in advance the operations necessary to ensure the effectiveness of technology. Thus, formation of butyric acid will lead to a strong acidification of medium and, accordingly, to inhibition of the processes of food waste degradation as well as hydrogen synthesis. Hence, it is necessary to provide in advance operation to neutralize culture liquid in technological cycle.

Thus, we have shown that application of thermodynamic prediction method of microbial interaction of with xenobiotics is necessary to develop novel universal environmental biotechnologies for processing of mixed food waste. For example, theoretically based biotechnology allows not only to destroy environmentally hazardous food waste effectively, but also to obtain environmentally friendly energy carrier - molecular hydrogen.

Mixed food waste is the most dangerous and toxic component of megapolises. There are no industrial technologies (physical, chemical, biological) that ensure effective processing of great volumes of food waste of modern megapolises at present time. We have developed the approach that allows to destroy quickly and efficiently food waste with decrease in their weight and volume. The distinctive feature of the approach is production of hydrogen in commercially significant quantities using selected anaerobic soil microorganisms. So, weight of waste was decreased in 94 times during four days. Moreover bacteria synthesized 123 liters of hydrogen from one kilogram of waste. Obtained data show that on the basis of our approach we can create profitable industrial biotechnology for food waste destruction and production of ecologically clean energy carrier - molecular hydrogen. Thermodynamic prediction also significantly increased the efficiency of methane fermentation of food waste. Weight of waste was decreased in 32-51 times during 11 days. Additionally, 60 liters of $\mathrm{CH}_{4}$ were synthesized from each kilogram of waste.

Thus, thermodynamic prediction of interaction of microorganisms with xenobiotics allows to choose optimal pathway for their destruction, as well as to obtain commercially valuable products - non-ferrous metals concentrate, clean water and energy carriers (hydrogen or methane).

\section{CONCLUSIONS}

We have shown that the algorithm for development of novel universal environmental biotechnologies was created using thermodynamic prediction method.

Distinctive features of biotechnologies are:

1. Fast and effective processing of a wide range of environmentally hazardous waste (rotting food and agricultural waste, synthetic organic compounds, metalcontaining wastewater, etc.);

2. Increase in efficiency of biotechnologies due to use of selected soil anaerobic microorganisms;

3. Obtaining of a wide range of valuable products: gaseous energy carriers (hydrogen, methane), solid fuel (unfermented lignin-cellulose residues), non-ferrous metals concentrate (chromium, copper, etc.) and clean water;

4. The possibility of scaling and replicating of typical technologies for special-purpose designation. 


\section{REFERENCES}

1. Pourbaix, M., Atlas of electrochemical equilibria in aqueous solutions, Pergamon press, Oxford, 1963 , p. 320

2. Tashyrev, A.B., (Theoretical aspects of microbial interaction with metals. Reductive transformation of metals), Mikrobiol. Zhurnal, Vol. 56, № 6, 1994, 76-88 pp. (Таширев А.Б., (Теоретические аспекты взаимодействия микроорганизмов с металлами. Восстановительная трансформация металлов), Мікробіол. журн., Т. 56, № 6, 1994, 76-88)

3. Tashyrev, A.B., „Theoretical aspects of microbial interaction with metals. Microbial accumulation of metals due to their stereochemical analogy to macroelements“, Vol. 56, N 6, 1994, 89-100, (Таширев, А.Б., „Теоретические аспекты взаимодействия микроорганизмов с металлами. Микробная аккумуляция металлов, обусловленная их стереохимической аналогией с макроэлементами, Мікробіол. журн., Т. 56, № 6, 1994, 89-100)

4. Sendel, E., Colorimetric methods of metal traces determination, Mir, Moscow, 1964, 899 p. (Сендел, Е., Колориметрические методы определения следов металлов, Мир, Москва, 1964, 899 с.)

5. Suslova O.S., P.V. Rokitko, K.M. Bondar, O.O. Golubenko, A.B. Tashyrev (Biochemical mechanisms of resistance to p-nitrochlorobenzene of karst caves microorganisms), Ukr.Biochem.J., Vol. 87, N5, 2015, 32-36.

6. Suslova O., V. Govorukha, O. Brovarskaya, N. Matveeva, H. Tashyreva, O. Tashyrev (Method for Determining Organic Compound Concentration in Biological Systems by Permanganate Redox Titration), Int. J. Bioautomation, Vol. 18, N 1, 2014 , 45-52.

7. Drugov Y. S., V.G. Berezkin, Gas chromatographic analysis of polluted air, Chimia, Moscow, 1981, 256 р. (Другов Ю.С., В.Г. Березкин, Газохроматографический анализ загрязненного воздуха, Химия, Москва, 1981, 256 с.)

8. Andreyuk E.I., A.B. Tashyrev, P.Ia. Smalko, (Prediction of microbial interaction with chromium compounds on the basis of thermodynamic calculations), Reports of the National Academy of Sciences of Ukraine, N 1, 2003, 149-156 (Андреюк
Е.И., А.Б. Таширев, П.Я. Смалько, (Прогнозирование взаимодействия микроорганизмов с соединениями хрома на основе термодинамических расчетов), Доповіді Національної Академії наук України, № 1, 2003, 149-156).

9. Schlegel G., General Microbiology: Trans. from the German, Mir, Moscow, 1987, 567 p. (Шлегель Г., Общая микробиология: Пер. с нем., Мир, Москва, 1987, 567 с.).

10. Leninger A.L., Principles of biochemistry, The John Hopkins University, School of Medicine, Worth Publishers, Inc., 1982, 367 p.

11. Tashyrev O., V. Romanovskaya, P. Rokitko, H. Tashyreva, I. Prytula, O. Suslova, V. Govorukha, Ie. Prekrasna, G. Gladka, (Autecology and taxonomy of bacteria isolated from extreme environments), Mikrobiol. Zhurnal, Vol. 79, N 1, 2017,100-113

12. Tashyrev, A.B., N.A. Matvieieva, H.O. Tashyreva, V.O. Romanovskaya, (Experimental rationale of thermodynamic prediction of redoxinteraction of microorganisms with metals-oxidizers $\left(\mathrm{Hg}^{2+}, \mathrm{CrO}_{4}{ }^{2-}\right.$ and $\left.\mathrm{Cu}^{2+}\right)$, Reports of the National Academy of Sciences of Ukraine, N 5, 2008, 174-180 (Таширев А.Б., Н.А. Матвеева, Г.О. Таширева, В.А. Романовская, (Экспериментальное обоснование термодинамического прогнозирования редоксвзаимодействия микроорганизмов с металламиокислителями $\left(\mathrm{Hg}^{2+}, \mathrm{CrO}_{4}^{2-}\right.$ и $\left.\mathrm{Cu}^{2+}\right)$, Доповіді Національної Академії наук України, № 5, 2008, 174-180)

13. Tashyrev O.B., (Interaction of microorganisms with cooper compounds), Agroecologichny Journal, №1, 2004, 42-46 (Таширев О.Б., (Взаємодія мікроорганізмів зі сполуками міді), Агроекологічний журн., № 1, 2004, 42-46

14. Tashyreva G.O., G.O. Iutynska, O.B. Tashyrev, (Resistance of Antarctic strains Enterobacter hormaechei and Brevibacterium antarcticum to ions of $\mathrm{Cu}$ (II) under different conditions of cultivation), Vol.71, № 4, 2009, С. 3-8 (Таширева Г.О., Г.О. Іутинська, О.Б. Таширев, (Стійкість до іонів міді(II) антарктичних штамів Enterobacter hormaechei та Brevibacterium antarcticum за різних умов культивування), Мікробіологічний журнал, Т.71, № 4, 2009, C. 3-8). 


\title{
ТЕРМОДИНАМИЧНА ПРОГНОЗА ЗА РАЗРАБОТВАНЕ НА НОВИ ЕКОЛОГИЧНИ БИОТЕХНОЛОГИИ И ПОЛУЧАВАНЕ НА ПОЛЕЗНИ ПРОДУКТИ ОТ ОТПАДЬЦИ
}

\author{
Олександър Таширев, Вира Говоруха, Олга Суслова, Хана Таширева, Олеся Хаврилюк
}

Резюме: Целта на настоящата работа е да се разработят ефективни екологични биотехнологии, които да позволят да се спре замърсяването на околната среда с широк спектър от токсични вещества и те да се превърнат в продукти с висока търговска стойност. За създаването на нови универсални екологични биотехнологии е използван методът на термодинамичния прогнозен алгоритъм. Отличителните характеристики на биотехнологиите включват: 1) бързо и ефективно изхвърляне на широка гама от опасни за околната среда отпадъци (разлагане на хранителни и селскостопански отпадъци, синтетични органични съединения и отпадни води, съдържащи метали и др.); 2) повишаване ефективността на биотехнологиите, дължащи се на прилагането на избрани почвени анаеробни микроорганизми; 3) получаване на широка гама ценни продукти: газообразни горива (водород, метан), твърдо гориво (неферментирал лигнин и остатьци от целулоза), концентрат от цветни метали (мед, хром и др.) и чиста вода; 4. способност за мащабиране и възпроизвеждане на типични технологии с определена цел. Получените инженерни и технологични параметри на универсалните биотехнологии показват перспективите за тяхното мащабно промишлено изпълнение.

Ключови думи: термодинамични прогнози, биотехнологии, опасни за околната среда съединения, синтетични органични съединения, метални отпадни води, биохидроген, биометан

Principal investigator Prof. Oleksand Tashyrev, Head of the Department

Zabolotny Institute of Microbiology and Virology of the NAS of Ukraine,

Department of Extremophilic Microorganism Biology, room 224

Address: Zabolotny str., 154, Kyiv, 03143, Ukraine

tel,: +380445263297

e-mail: tach2007@ukr.net

\section{Researcher Vira Govorukha, PhD}

Zabolotny Institute of Microbiology and Virology of the NAS of Ukraine, Department of Extremophilic Microorganism Biology, room 224

Address: Zabolotny str., 154, Kyiv, 03143, Ukraine

tel,: +380445263297

e-mail: vera_govor@mail.ru

\section{Researcher Olga Suslova, PhD}

Zabolotny Institute of Microbiology and Virology of the NAS of Ukraine, Department of Extremophilic Microorganism Biology, room 224

Address: Zabolotny str., 154, Kyiv, 03143, Ukraine

tel,: +380445263297

e-mail: olga.suslova11@gmail.com

\section{Postdoc, principal investigator Hanna Tashyreva, PhD}

Center for Tropicalization, Center for Research Management and Innovation, National Defence University of Malaysia,

Address: Ground Floor, Research Management Complex, Camp Sungai Besi, 57000 Kuala Lumpur tel,: +60 3-90513400 ext 3085

Zabolotny Institute of Microbiology and Virology of the NAS of Ukraine, Department of Extremophilic Microorganism Biology, room 227

Address: Zabolotny str., 154, Kyiv, 03143, Ukraine

e-mail: anna.tashyreva@gmail.com, hanna.tashyreva@upnm.edu.my 